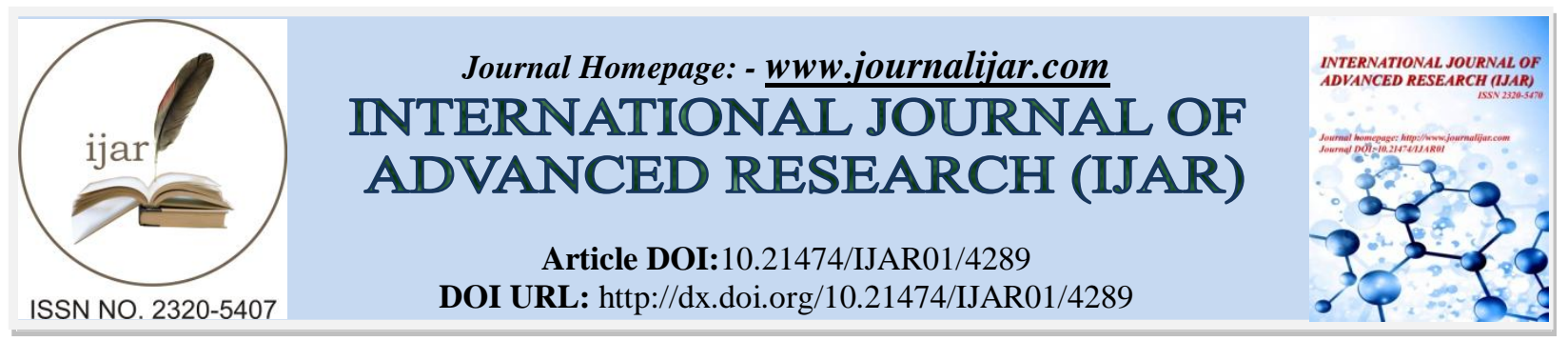

RESEARCH ARTICLE

\title{
UPGRADATION OF STREETS IN INFORMAL AREA IN KABUL CITY.
}

Saifullah Amin ${ }^{1}$ and Dr. Supriya Vyas ${ }^{2}$.

1. Research scholar M. Plan, IV-Semester, Department of Architecture and Planning Maulana Azad National Institute of Technology, Bhopal.

1. Assistant Professor Department of Architecture and Planning Maulana Azad National Institute of Technology, Bhopal.

\section{Manuscript Info}

\section{Manuscript History}

Received: 28 March 2017

Final Accepted: 30 April 2017

Published: May 2017

Key words:-

Informal settlements, upgrading, physical infrastructure.

\section{Abstract}

The reason of growth and formation process of informal settlements varying in location, size, density, building quality, illegality, risk situation, and level of consolidation and integration. However, they have some similar characteristics, but illegality in land titling or property, worse livingconditionsof dwelling, the lack of urban infrastructures are the main elements which separate informal area or town fromthe formal area and town. This variety makes the design of public policies and actions for all informal areas more difficult.

On the other hand, despite all international and national effortsfor the growth of informal settlements,slums are emerging not only in backward countries but in the developed countries too. Mostly expert believes informal settlements could be totally avoided is a wrong thought due to many reasons.

One of the vital and effective way is upgrading which decreases the growth of informal settlements and provides better life conditions for the present residence. In Kabul city approximately $76 \%$ area is covered with informal settlements which is so high percentage due to a large segment of the cities require upgrading. On the other hand, the financial resource of the Afghan government very limit.Due to not only Kabul municipality authorities, but the international agencies such as UN-Habitat, JICA etc. also recommended the upgrading policy for Kabul city.

Copy Right, IJAR, 2017,. All rights reserved.

\section{Introduction and Background:-}

Afghanistan is a Muslim country, with the majority of Sunni and Pashtuns and Minorityof the Shi'as. The people of the country speak with two principal languages Pashto (the language of Pashtuns) and Dari (a variant of Persian). Afghanistan has a total surface area approximately $647,500 \mathrm{~km}^{2}$ and more than $75 \%$ is occupied by mountains and hills. Afghanistan is one of the world's least developed and poorest country due to more than 3.5 three and half decades of war and still the conflicts is continues.

Until now, Afghanistan isn't have balanced, systematic control and properly organized system for the urbanand city development due to many factors such as: internal and external political conflicts, economic situation, lack of experience of urban planners, rapid growth of population, geographical location etc.

Corresponding Author:-Saifullah Amin.

Address:-Research scholar M. Plan, IV-Semester, Department of Architecture and Planning Maulana

Azad National Institute of Technology, Bhopal. 
According to World Bank (2015), Afghanistan has 32, 5 million population. More than 30\% of the population live in urban areas. In Kabul metropolitan city more than $50 \%$ of the urban population live, around (5.5 million people live in Kabul city). Shortages of Housing and highland prices, lack of strength and good building materialsand lack of a new master plan as well as difficult administrativeprocedures based on ideal norms rather than the realities of local circumstances have made a rise in informal construction unavoidable.

Kabul the historical city which is becoming the capital of Afghanistan in 1775 . The city was beautifully shaped and good geographical location. Kabul is the 64th largest and the 5th fastest growing city in the world. The growth of population in the recent years is very high due to the return immigrants, job opportunity and safety of tenure and life. In the period of war Kabul was very hardly damage, mostly the existing infrastructure was also severely damaged during this period.

The total area of Kabul city is $4462 \mathrm{~km}^{2}$ and located $34 \mathrm{~N}, 69 \mathrm{E}$ coordinate and the total population is estimated according to the World Bank about 5.5million in 2012. The population has grew over the last 10 years very fast, the demographic growth rate is around $17 \%$ per year.The city has grown mostly through the construction of informal settlements, which now shelter about $60 \%$ of Kabul population, where more than $12 \%$ area is hill side informal settlements. Kabul the capital city has all ethnic groups (Pashtuns, Tajak, ozbak, hazara, etc.). The central part of the City is more ethnically mixed.

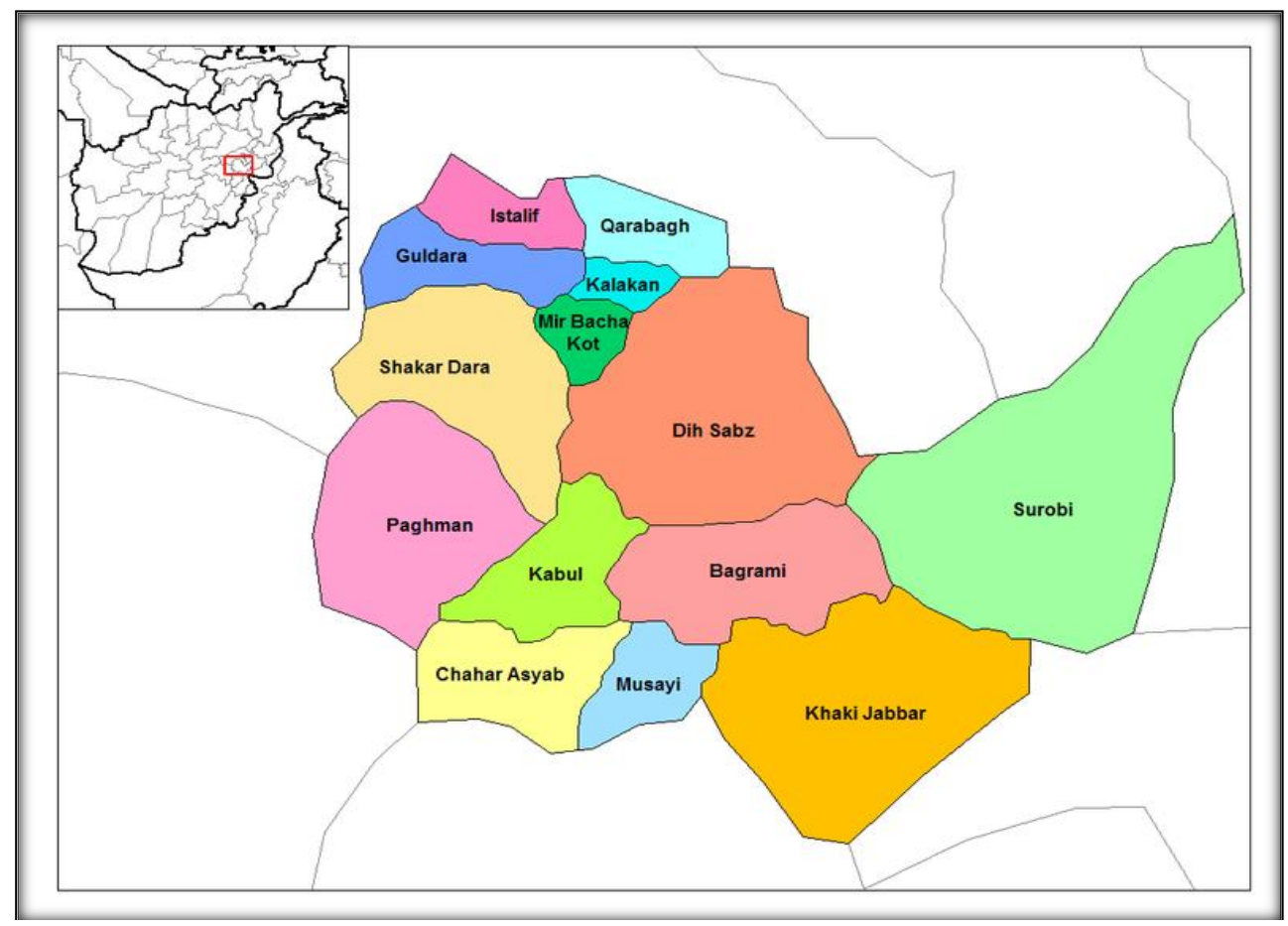

Map.1:-Map. 9:- Kabul province districts, source: Google Kabul maps.com.

According to UN-Habitat upgrading Refers to the physical, socio-economic and environmental improvements to slums undertaken cooperatively among citizens, community groups and local authorities with a view to alleviating the poor living standards of slum dwellers (UN-Habitat, 2003).

According to World Bank (1996), say on the elaborate word that upgrading is the most basic level, which involves improving the physical environment of the slums and squatter settlements. This includes improving and installation of basic infrastructure like water, sanitation, waste collection, access roads, footpaths, storm water drainage, lighting, public telephones and land regularization among other things. The Cities Alliance (2002).

It is generally agreed that the first person to propose an alternative way of thinking about upgrading was John F. C. Turner in the late 1960s. An architect and a scholar, Turner developed a theory of settlement upgrading which 
focused on the community's right to create their own plans and the government's role as a provider of resources and services (Abbott, 2002).

\section{Master plan of Kabul city:-}

The existing development of Kabul city is the product of three master plans which we prepared different times. The first master plan was built in 1962 by Afghan experts for 0.8 million people in $237.8 \mathrm{~km}^{2}$ area. Due to The rapid growth of population the master plan required to be updated.Hence the second master plan was prepared in 1979 for 1.416 million people in $299 \mathrm{~km}^{2}$ area by Soviet expert and the United Nations Educational, Scientific and Cultural Organization (UNESCO). The development of the knowledge and other requirements again required for updating of the master plan. The third master plan was established by Afghan and Russian expert in 1978 for 2 million people in $323 \mathrm{~km}^{2}$ area which is still used. The summarization of the master plan is in table-1.

Table 1:- Kabul city master plan summarization.

\begin{tabular}{|c|c|c|c|c|}
\hline Item & Approved Year & Horizon year & Planned populationMillion & Cover area \\
\hline First master plan & 1962 & 1987 & 0.8 & 237.8 \\
\hline Second master plan & 1979 & 1995 & 1.4 & 299 \\
\hline Third master plan & 1978 & 2002 & 2 & 323.3 \\
\hline
\end{tabular}

Table. 1:- Master plan summary, Source planning team based on special reference of UN-Habitant of Kabul city.

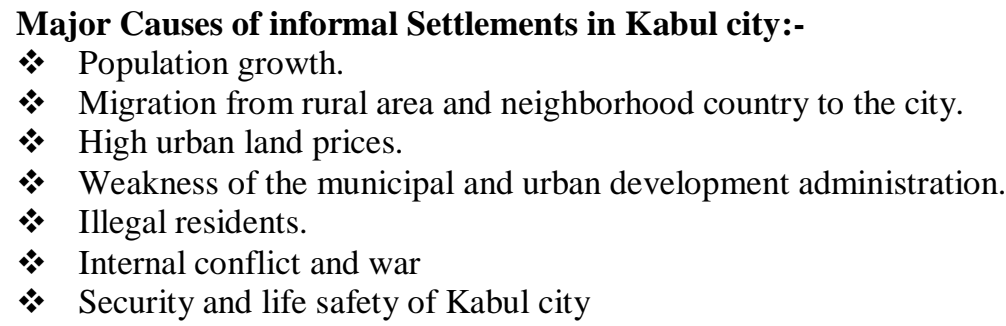

\section{Projects for Upgradationin Kabul city: A case study:-}

In Afghanistan, especially in Kabul city not only government but International NGO such as UN-Habitat also work for the upgrading of Kabul city, according to UN-Habitat in Afghanistan the investments value on 30 projects from(2008-2016) are \$291,435,060. These projects include: shelters, potable water, sanitation, and other basic services.

For upgrading of informal settlements Kabul municipality considered one big program under the title of the Kabul municipal development project (KMDP), which was supported by the World Bank. In this program the important objectiveswere to increase access municipal services in residential areas and upgrade infrastructure in Kabul city. The total cost of upgrading infrastructure is \$ 75.5 million dollars. (Republic of Islamic Afghanistan Kabul municipality 2014 report).

In addition, USAID contract with Afghan NGO to improve the physical environment of 250 informal households in district 13 of Kabul city, the area was identified by Kabul municipality. This program is community based upgrading program (CBU), and the decision is that to paved the unpaved street in district 13, which is completed in 11 month the total cost of the project is $\$ .170 .000$, and paved around $3 \mathrm{~km}, 26$ types streets with different width, $15 \%$ contributed by community people as a labor. The street map and number are shown in figure- 3 . 


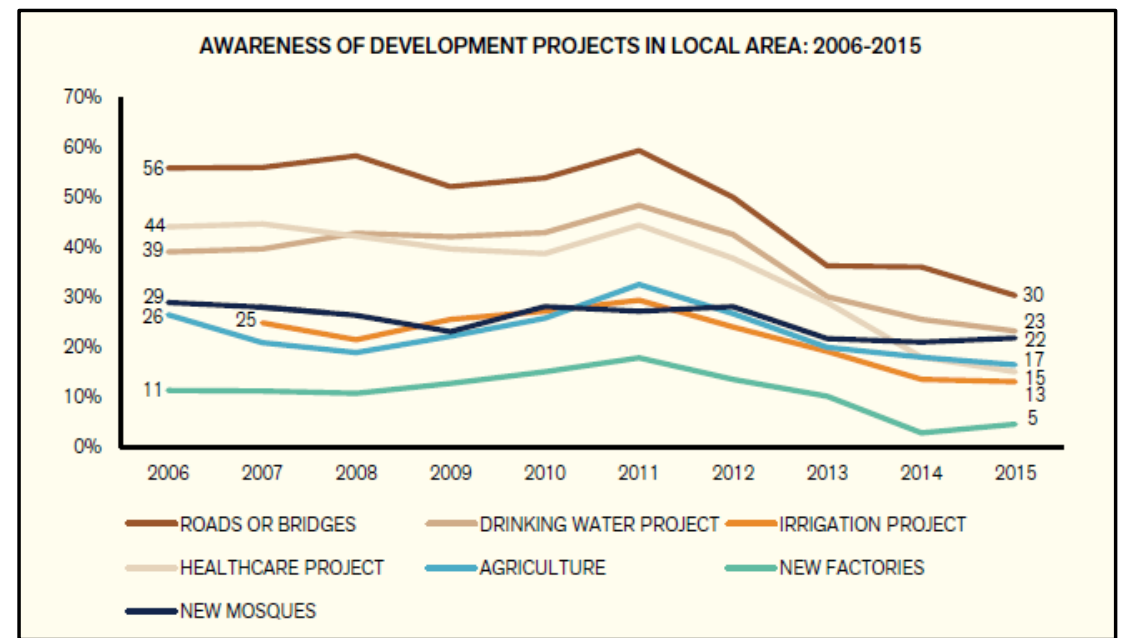

Figure 1:-Upgraded project in Afghanistan, Source: Asia Foundation 2015 Report.

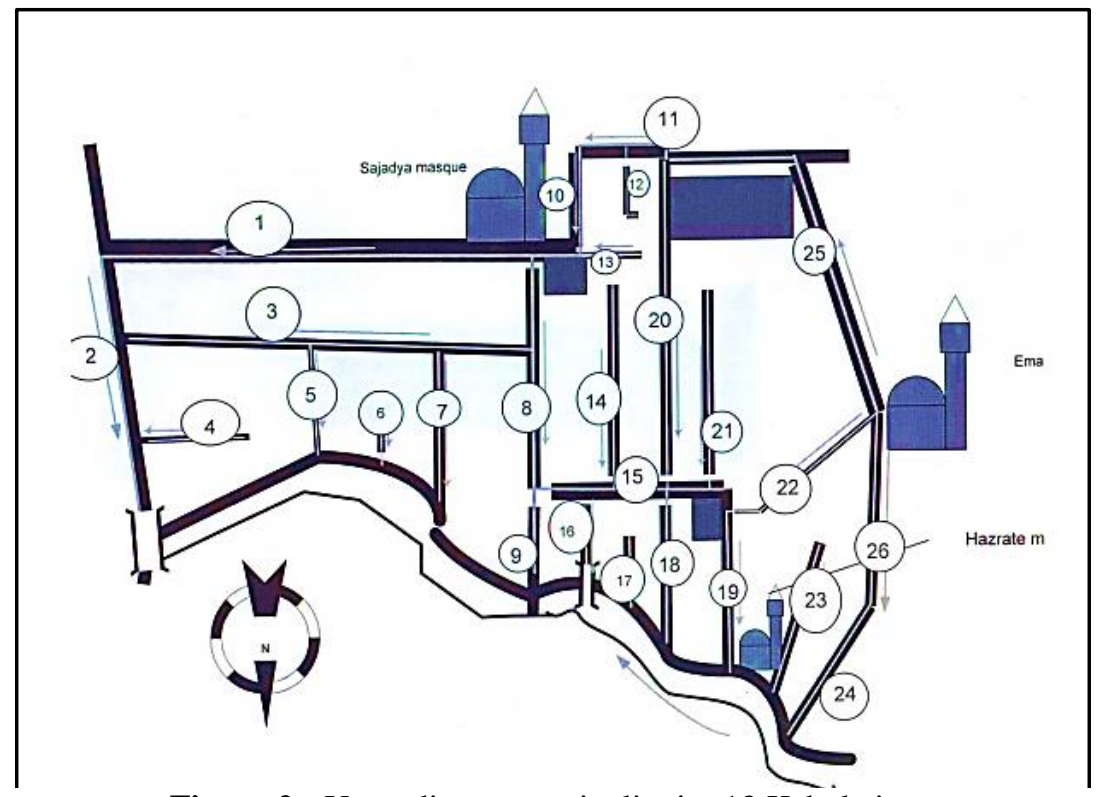

Figure.2:- Upgrading streets in district-13 Kabul city.

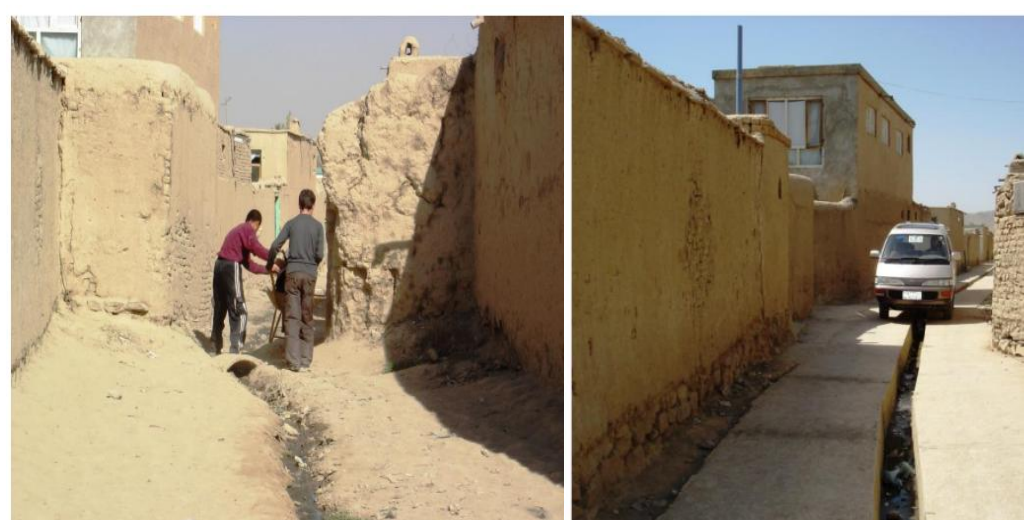

Figure 3:-Before and after upgrading the streets of district 13 Kabul city. 


\section{Proposal for Upgrading of streets In Kabul City:- Study Area Qala-E-Wahid:-}

The study area is nominated by Qala-e-Wahid and mostly proposed for residential purpose. Although some part of the area is used for commercial activity. This site is near to the major provincial road which is connectedGhazni, Wardag and other province to Kabul city. The main issues in the site is irregular built of self-house by people and lack of basic infrastructure and environmental degradations. Duo to it basically required for upgrading. The settlements of the area are suffering from the lack of basic infrastructure, especially in winter season when the area is covered by snowfall or in the case of heavy rainfall. The residence of the site is opposed to any relocation, particularly the owners of land. Due to redevelop or clearing of the area hasbrought allot of social and economic problems. In situ- upgrading is the only successful way for improvements in the area.

The total surface area of the site is 66.7254 Hectare .The longitude is 69,104 and the latitude is 34,516 . The selected area is located near to Koti-e-Sangi .The area is separated in north by major provincial road (company road) and in the south it is separated by Paghmanriver, east side is surrounded by mixed residential, commercial area and the western side is also surrounded by residential area.
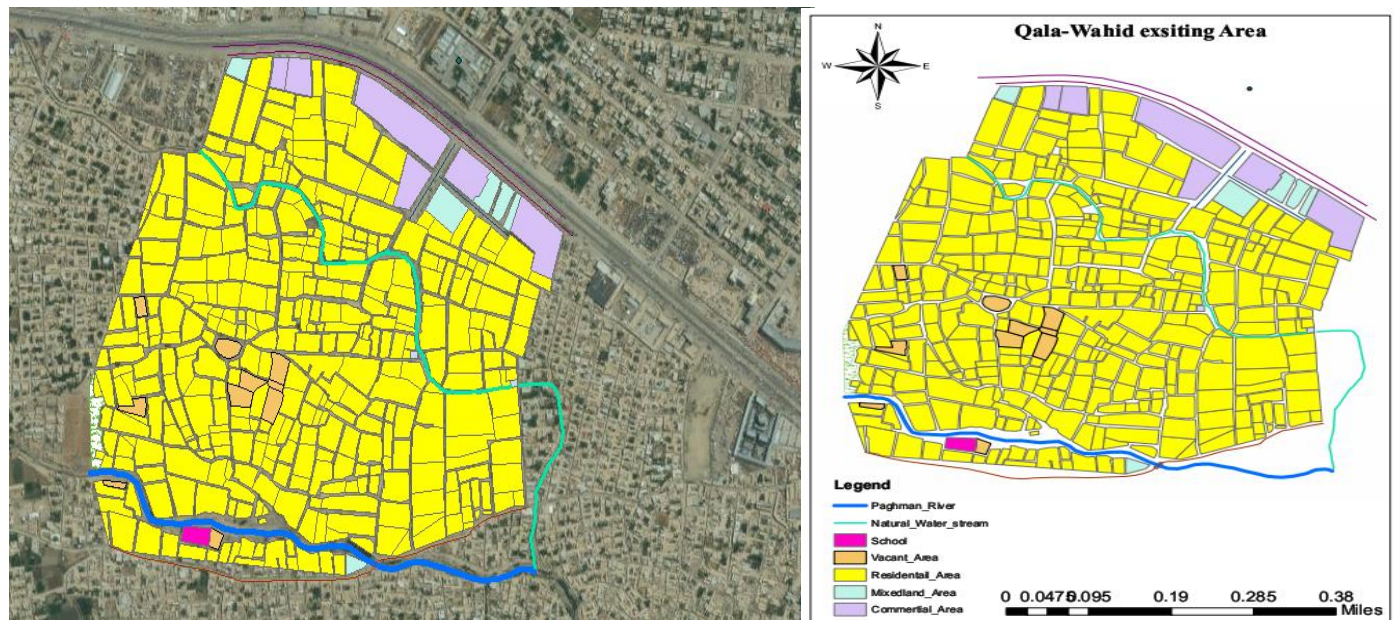

Map. 2:-Qala-e- Wahid location with surrounding and land use .

According to the site layout, all of the streets are irregular, narrow, dead end and lack connectivity due to which, improvement of this site is essential. But like it is clear earlier that the study only considers upgrading the area without displacement of residences. On the other hand, upgrading of streets plays very important role and lead to plannedphysical infrastructure such as water supply line, sewage, drainage and solid waste. On the other hand the elevation profile of the area starts from the high point to the low point north to south. The highest point has a1835 meter elevation and lowest point has a 1823 meter elevation. The difference between highest and lowest is 12 meter.

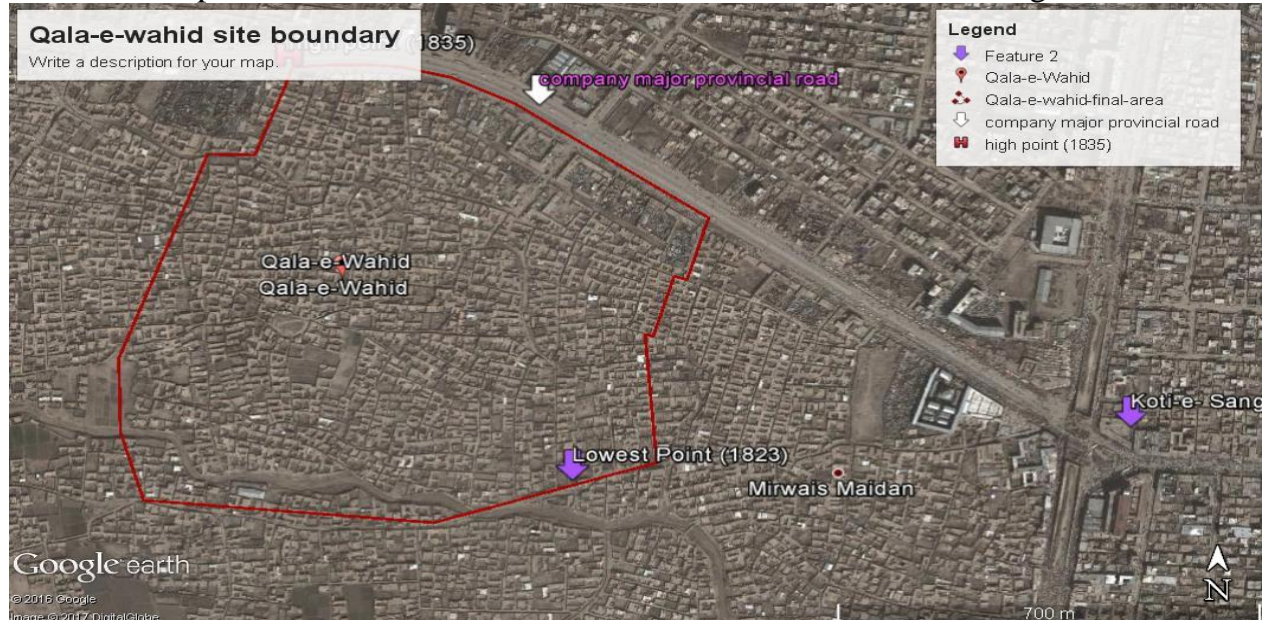

Map 3:-Qala-e-Wahid boundary area. 


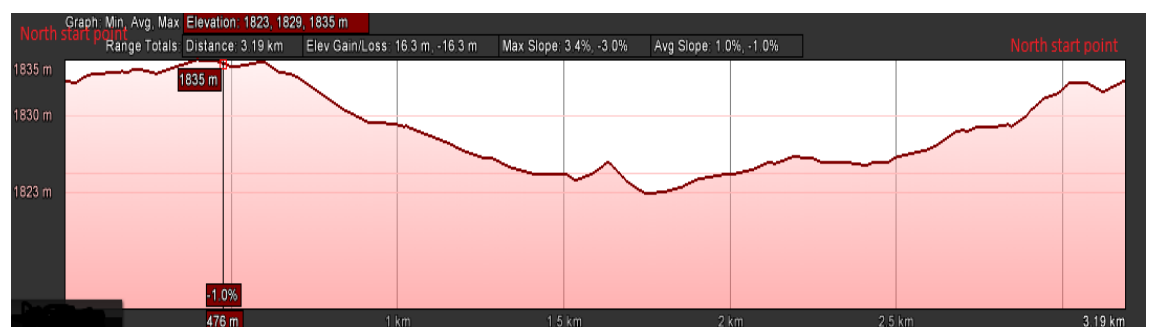

Land use of the site:-

Figure 4:- boundary area profile of Qala-e-Wahid.

The majority area of the site is covered by residential self-constructed building which is built from local materials. This target area is low rise residential self-built house and most part of the area is covered by one story house which is built without any proper planning and design. However, in the center and near to company road residential buildings have two and three stories and have a good architecture view. From the total area of the site approximately $74 \%$ is covered by residential building, $7 \%$ is occupied by commercial building, $15 \%$ is covered by residential street roads, $2.9 \%$ is covered by Paghman river $0.5 \%$ is covered by public and semi-public buildings . The total household is approximately 752 in 2017 . See the land use of the area in table-2.

Table 2:- land use of Qala-e-Wahid.

\begin{tabular}{|l|c|c|}
\hline Land used type & Percentage & Area by Square meter \\
\hline Residential area & $73.81 \%$ & 492566 \\
\hline Commercial area & $6.86 \%$ & 45779 \\
\hline Masjeedsharif & $0.1 \%$ & 676 \\
\hline School & $0.3 \%$ & 2026 \\
\hline Mixed land use & $0.18 \%$ & 1200 \\
\hline Stream line & $0.8 \%$ & 5272 \\
\hline River & $2.9 \%$ & 19531 \\
\hline Road & $15 . \%$ & 100204 \\
\hline Total Land used & $100 \%$ & 667254 \\
\hline
\end{tabular}

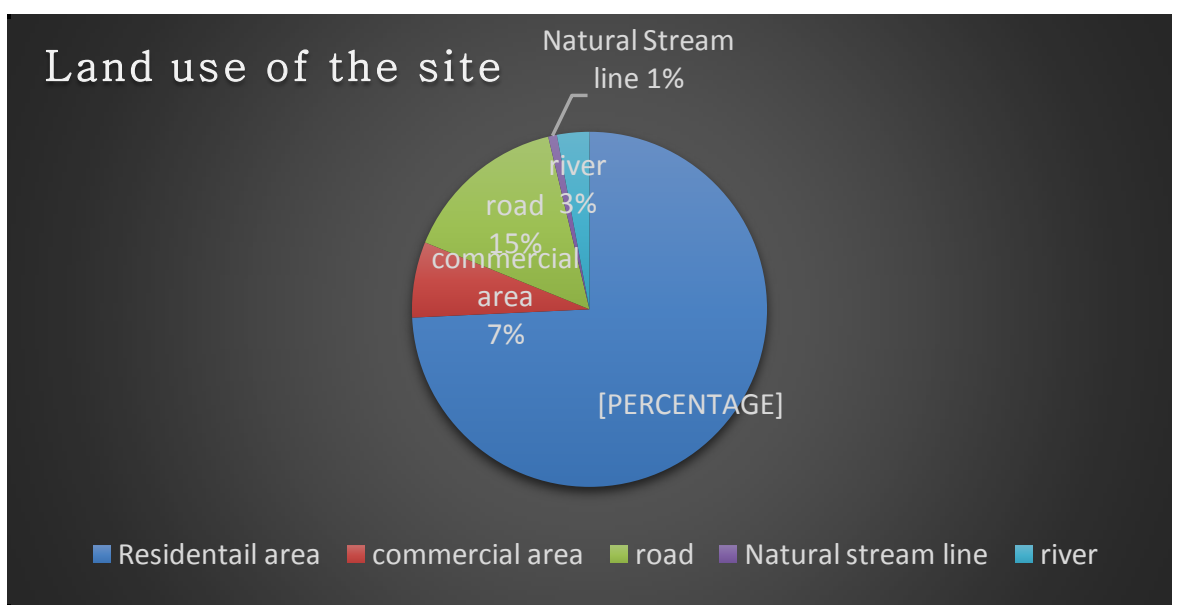

Figure 5:- land usepercentage ofQala-e-Wahid.

\section{Demographical Analysis of the Area:-}

According to JICA survey 2011 the gross population density for residential area in district -5 is 212 which shown on Table 4-1. Based on this the population is calculate for the area on the below way: 


\begin{tabular}{|lccccc|}
\hline \multicolumn{5}{c}{ Table 4.1: Existing and Future Gross Population Density by Type of Residential Area } \\
\hline Iteln & & Unit & \multicolumn{2}{c|}{ Planned Area } & Unplanned Area \\
& & & Detached & Nulti-story \\
\hline Existing population density & Net & person/ha & 379 & 450 & 277 \\
& Gross & person/ha & 212 & 368 & 246 \\
\hline Future population density & Net & person/ha & 330 & 450 & 240 \\
& Gross & person/ha & 180 & 370 & 180 \\
\hline Source: & Planning Team & & & &
\end{tabular}

For 2011:-

Figure 6:-population density of district-5

The total Area of the site is 667254 Square meter which is equal to 66.7254 Hectare.

Gross population density $=$ numbers of people divided by land Area

$$
\begin{gathered}
\text { GrossDensity }=\text { Numbersofpeople } / \text { LandArea } \\
\text { Numbersofpeople }=\text { GrossDensity } \times \text { LandArea }
\end{gathered}
$$

Numbers of people $=212 \times 66.7254=14145$ person

The number of house hold is equal = number of people divided by house hold size

The average house hold size of the site is equal to 7.4 person. So hence:

Number of family = number of people divided by family size

Number of family $=14145 / 7.4=1911$ family

Number of house will be calculate in below way:

Number of house $=$ number of family divided by the number of family live in one house

Number of the family live in one house is 2.9

Number of house $=1911 / 2.9=660$ house

(i) For 2017

The calculation of population by logarithmic formula is calculate on the below way

Where:

$$
P_{t}=P_{0} e^{r t}
$$

$\mathrm{P}_{\mathrm{t}}=$ Estimated population

$\mathrm{P}_{0}=$ is base year population. In 2011 in the selected area is 14145

$\mathrm{e}=$ is the base of Natural logarithm

$\mathrm{r}=$ is population growth rate. Growth rate for Kabul is $2.22 \%$

$\mathrm{t}=$ is time interval form 2011 to 2017

$\mathrm{P}_{2017}=14145 \times \mathrm{e}^{0.0222 \times 6}$

$$
P_{t}=P_{0} e^{r t}
$$

$\mathrm{P}_{2017}=16153.7=16153$ person.

Table 3:- PopulationCalculation for the target area (Qala-e-Wahid) from 2011 - 2017.

\begin{tabular}{|c|c|c|c|c|}
\hline Year & Population & Density & Family Number & house hold number \\
\hline 2011 & 14145 & 212 & 1911 & 659 \\
\hline 2012 & 14461.55 & 216 & 1954 & 673 \\
\hline 2013 & 14785.19 & 221 & 1997 & 688 \\
\hline 2014 & 15116 & 226 & 2042 & 704 \\
\hline 2015 & 15454 & 231 & 2088 & 720 \\
\hline 2016 & 15800 & 236 & 2135 & 736 \\
\hline 2017 & 16153 & 242 & 2182 & 752 \\
\hline 2018 & 16515 & 247 & 2231 & 769 \\
\hline 2019 & 16884 & 253 & 2281 & 786 \\
\hline 2020 & 17262 & 258 & 2332 & 804 \\
\hline
\end{tabular}

\section{Criteria for choosing proposed street pattern:-}

1. Major road: north is surrounded by major provincial and south is surrounded by arterial road, due to this the site should be connected with these two roads for the future development. In the same way the connection of these two roads by 13 meter wide road which is passed from the center of the area is also required. 
2. Slope required for infrastructure: Slope is another important criteria for designing of physical infrastructure such as water supply, sewage, and drainage. Proper Slope also helps in economic design of infrastructure. Based, on this the elevation profile of the area shows that the north part is the high in elevation the height of which is 1835 meter and lower elevation is south side which is 1823 meter. It means that the slope is from north to south and from west to east. Therefore the new proposed road helps in planning physical infrastructures: water supply, sewage and drainage also planned from north to south and east to west to provide useable and economical system for the mentioned infrastructures.

3. Maintain the existing alignment: The residents of the area oppose any kind of displacement due to which the existing road isincreased in width and alignment is maintained.

4. Source of water supply: The water source of the city is also located on the north side of the area due to which it is very easy to connect the water line with this source of the water.

5. Network of sewage: In the south side of the area is the trunk network of the sewage due to which it is very easy to manage sewage network in this direction.

6. Existence of Paghmanriver: For drainage system the only place to manage rain water is the Paghmanriver.Water can easily flowto this River.

7. Existenceof bridge on PaghmanRiver in the south side.

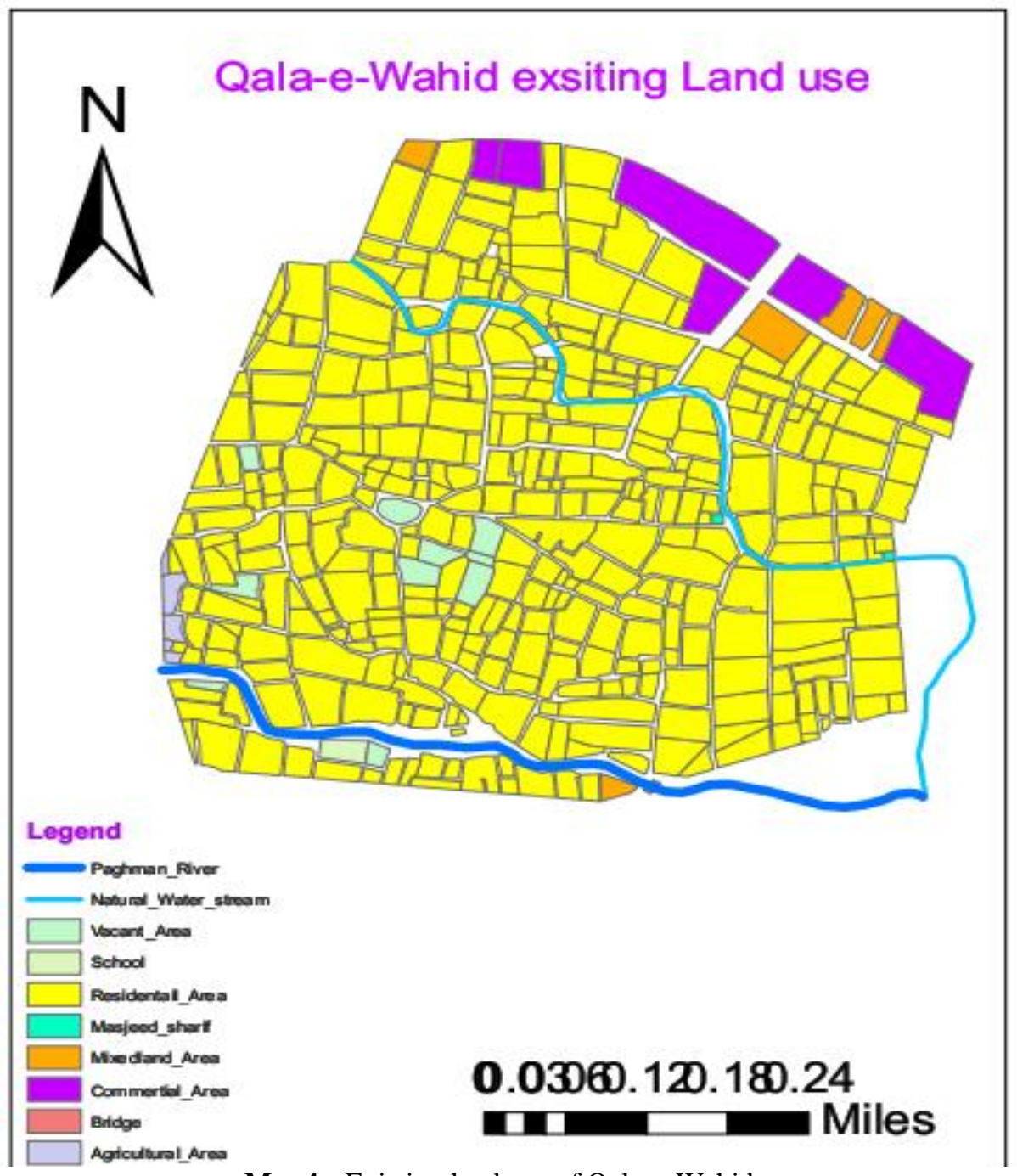

Map4:- Existing land use of Qala-e-Wahid.

\section{Proposal for New Proposed Streets:-}

The proposal concerns with two major elements: width of road and pattern of connection of road. 
1. Width of roads

2. Connectivity pattern

I. The first one that is the width of roads,concern with many factors such as traffic volume, location, purpose, speed of vehicle, function etc. But many countries limit the width of the road. According to JICA and Kabul municipality, urban roads based on function were categorizedas below table 5-1. Due to this consideration my study area is urban and residential. For the proposed roadIV category is selectedwhere the width is limited from $(8-20)$ meter.

Table 4:- Road design standard for Kabul city. Source: JICA planning Team.

\begin{tabular}{|c|c|c|c|}
\hline Design class & $\begin{array}{c}\text { Design speed } \\
(\mathrm{Km} / \mathrm{h})\end{array}$ & $\begin{array}{c}\text { ROW } \\
(\mathrm{m})\end{array}$ & $\begin{array}{c}\text { Default } \\
(\text { signals/km })\end{array}$ \\
\hline I & $70-60$ & $40-70$ & $0.5-2.0$ \\
\hline II & $60-40$ & $30-60$ & $2.0-4.0$ \\
\hline III & $40-30$ & $20-30$ & $4.0-6.0$ \\
\hline IV & 30 & $8-20$ & $4.0-6.0$ \\
\hline
\end{tabular}

Based on this and the economy and future development of the area,the study considers three kinds of road, 13 meter right of way for main street, 11 meter right of way for medium size street and 8 meter right of way for common street whose cross sections are shown in the below figures.

\section{3 meters Right of Way Street (ROW):-}

This street is located near the middle part of the area which connects two main north and south roads. Mostlycommercial areas exist in the north and residential area is located in the south part of Qala-e-Wahid. The total length of the 13 meters road is 637 meter. This road has two lane with 3 meter width, 1.5 meter shoulder to each side in 1 meter drainage ditch with each side and has 1 meter pedestrian to each side. More details is shown in figure -7 .

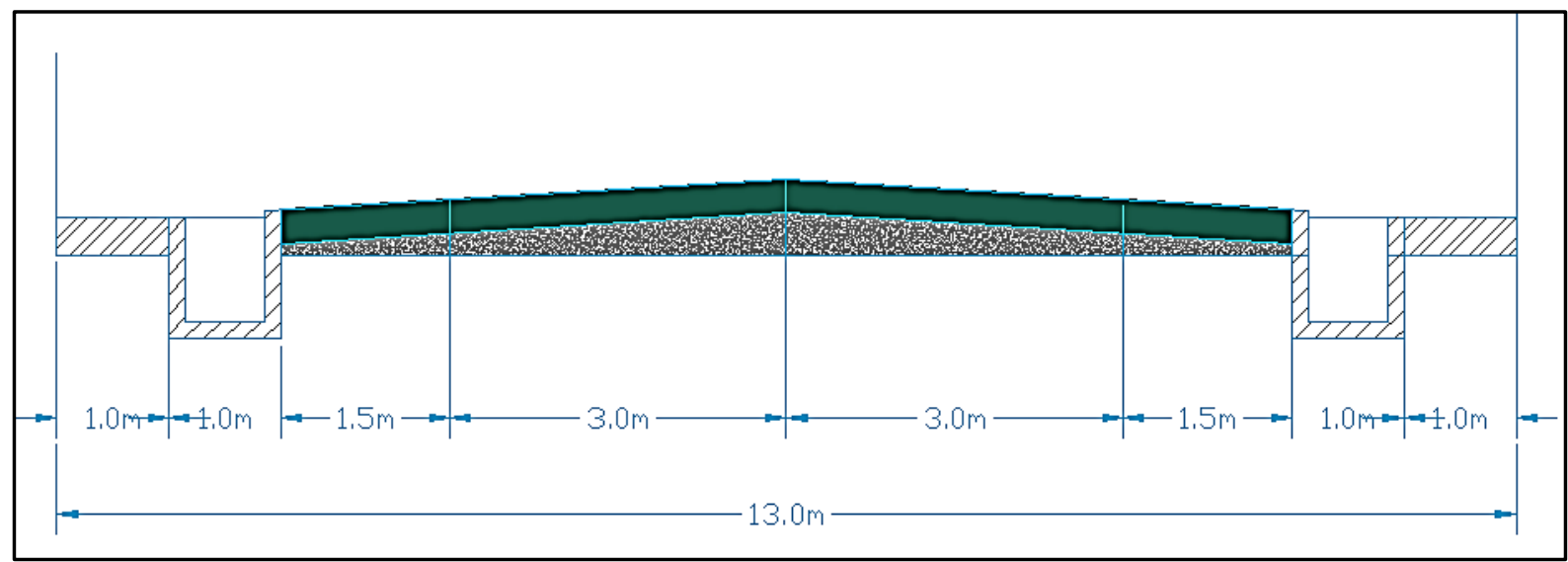

\section{1 meters Right of Way Street:-}

Figure.7:-13 meter street road cross section.

For medium size street 11 meters width road is selected which requires minimum modification of the existing street. These roads connect west side to the main road (13 meters road). The total length is $1683 \mathrm{~m}$. These roads have two lane with 3 meter width, 1.5 meters shoulder on each side and have 1 meter drainage each side. For more details look to figure -8 . 


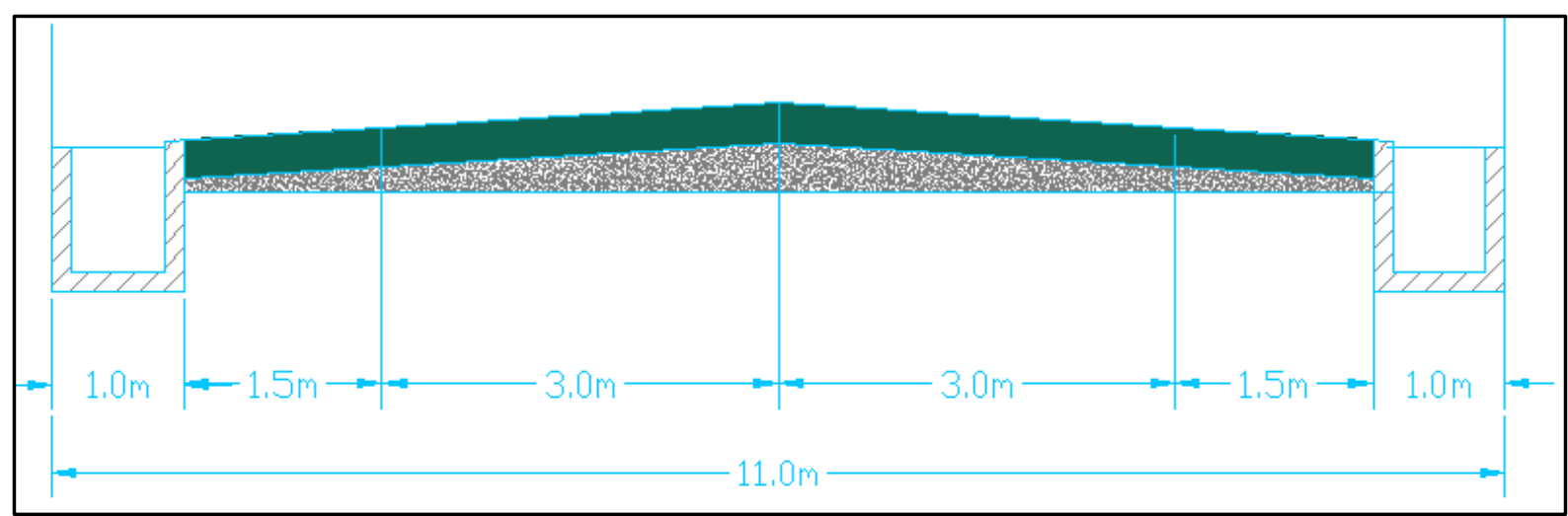

Figure 8:- 11 meter street road cross section.

\section{8-meters Right of Way Street:-}

This is the minimum standard size for the urban road, due to which it is selected for Common Street. This road is mostly link road which connects two mediums or main roads. The total length is 3209 meters. These streets are one lane which has 1.5 meter shoulder on each side and 1 meter drainage ditch to each side. The cross section of the road is shown in figure -9 .

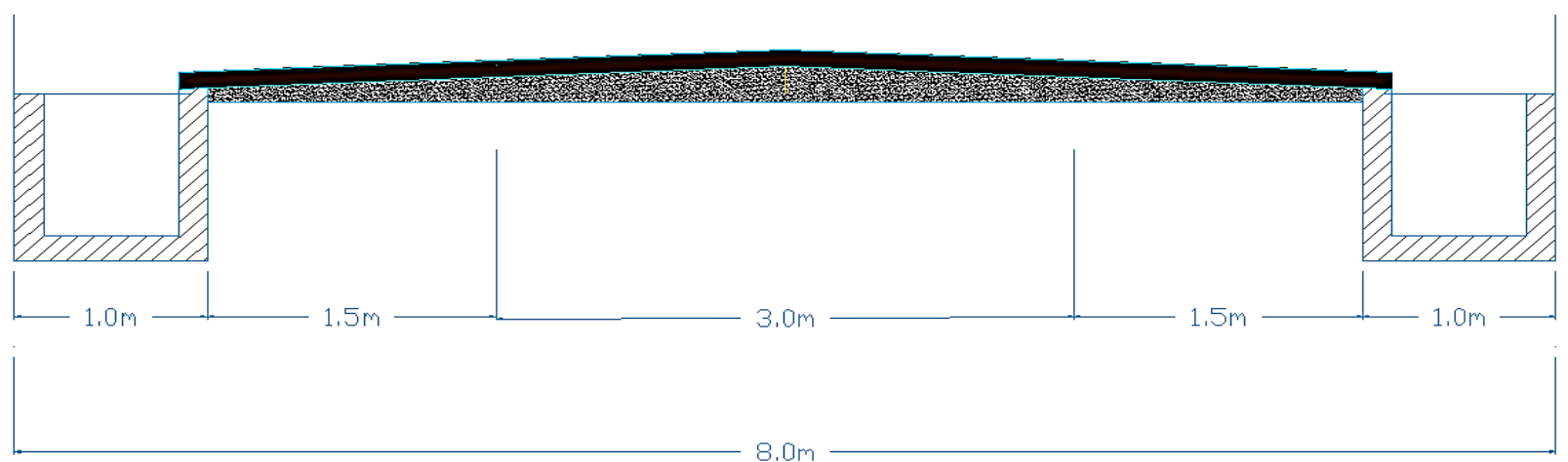

Figure 9:-8 meter street road cross section.

Table 3:- summary table of the proposed new Streets in the area.

\begin{tabular}{|c|c|c|c|}
\hline Item & Width $(\mathrm{m})$ & Length $(\mathrm{m})$ & Area $\left(\mathrm{m}^{2}\right)$ \\
\hline Main Street & 13 & 637 & 8281 \\
\hline Middle Street & 11 & 1683 & 18513 \\
\hline Common Street & 8 & 3209 & 25672 \\
\hline Total & & $5529 \mathrm{~m}$ & 52466 \\
\hline
\end{tabular}

On the other hand, the main street required $45 \%$ extra area from the residential area which is equal to $3726 \mathrm{~m}^{2}$ and Middle Street required $50 \%$ extra area from the residential area which is equal to $9380 \mathrm{~m}^{2}$. The common street required 30\% extra area from the residential area which is equal to $7700 \mathrm{~m}^{2}$. The total occupied area is $20806 \mathrm{~m}^{2}$. Based on this $39 \%$ extra area is required of total streets area. Thus new area of land is required to be occupied from the land ownersfor which the government should give compensation to the landowners. 


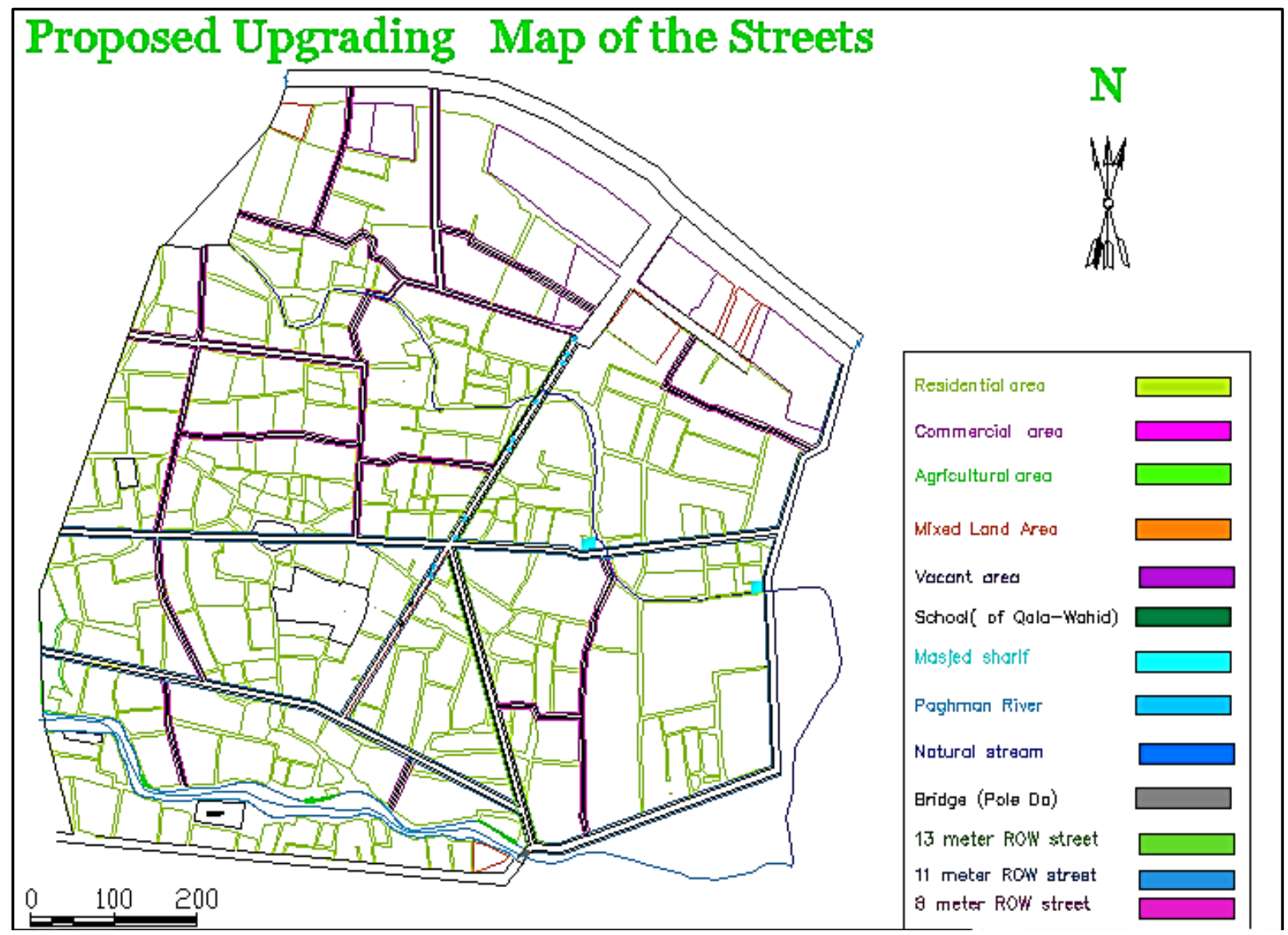

Map 5:-Proposed streets of Qala-e-Wahid by author 2017.

The second Connectivity pattern of streets is another important aspect of planning which plays a very important role on the layout and economic design of infrastructure. Mostly in many countries grid, circular, hexagonal are usable pattern in planning a city. But ancient city such as Whitechapel is one of the organic pattern type city which still exists and people still use the road in London. The countries where the rapid growth of population is there, they develop with organic type and mostly the slum area is also has an organic layout. Due to this, the study area also has an organic layout with very narrow Street and dead end Street. On the other hand, the proposed upgrading model is in situ upgrading model which does not displace the residents. So it is very difficult to change the street system like grid, circular or other regular type.Due to in this proposal the organic type patternis developed.
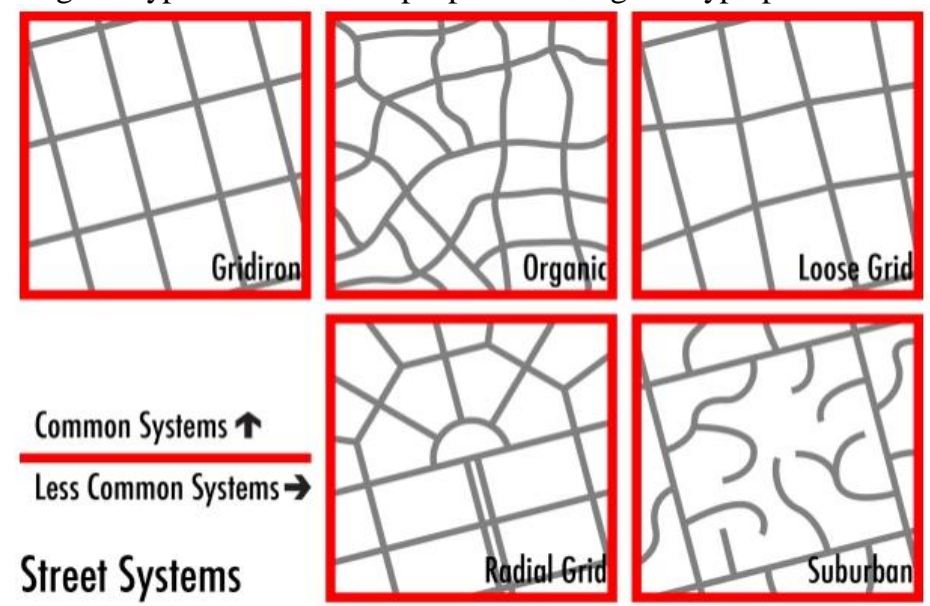

Figure 10:- type of street in informal area. 


\section{Conclusion:-}

Generally, the growth of informal settlements brings many social, economic and environmental problems. Due to the governmental responsible sectors are an effort to avoid from the growth of informal settlements and provide healthy, enjoyable and safe environment for the people.

In Kabul city, where the growth of informality is very high and $76 \%$ area is occupied by informal settlements it is very difficult for the government to improve all the informal areas in less time.

On the other hand, upgradation is the only suitable way to improve the life of informal settlements and provide better life conditions for the people in Kabul city. The government should by make upgrading policy in such a way to gradually upgrade the informal area and planned another satellite city on the periphery of Kabul city to avoid from new informality.

To provide better life conditions for informal settlements in Kabul city municipality should be more focus on the upgrading of physical infrastructure, especially in road and accessibility.

\section{Reference:-}

1. UNCHR (2010) 'Draft Report - Protection Profiling of the Informal Settlements in Kabul City and Surrounding Areas', unpublished.

2. Alain Bertaud. Urban Land Management in Afghanistan Kabul Urban Development. 2005. World Bank

3. Jo Beall and Daniel Esse. Shaping Urban Futures: Challenges to Governing and Managing Afghan Cities. 2005. AREU

4. The Study on the Kabul Metropolitan Area Urban Development in the Islamic Republic of Afghanistan (Project Formulation Study), September 2006, Japan International Cooperation Agency (JICA)

5. Municipal Management Manual for Afghanistan, 2002, USAID.

6. A tale of two cities: Restoring water services in Kabul and Monrovia, October 2014 UNEP.

7. Kabul Urban Policy Notes Series, about Informal settlement in Kabul 2004 World Bank.

8. TO0FAN NABIZADA, Doctoral DissertationA Study on the Spatial Structure of Houses and Open Spacesby the Analysis of Physical Improvements and Daily Activitiesin the Typical Residential Areas in Kabul City, December, 2012.

9. Danish Refugee Council, Protection Problems in Kabul Informal Settlements (KIS), Qualitative Research in 5 KIS Sharake Police, Kabul Nandari, Dashd-e-Quasaba, Hewadwall, ArghandeOctober 2012.

10. OSHA (2013) Kabul Informal Settlements [online]. Available at https://afg.humanitarianresponse.info/visuals/3w-and-map-kabul-informal-settlement-8-april-2013 [Accessed 07 July 2014].

11. World Bank (2006) why and how should Kabul upgrade its informal settlements [online]. Available from: http://documents.worldbank.org/curated/en/2005/12/7015047/kabul-upgrade-informal-settlements [Accessed 07 July 2014].

12. UN-HABITAT (2003) the Challenge of the Slum: Global Report on Human Settlement. London Earth scan.

13. http://www.aims.org.af/

14. http://www.undp.org.af

15. http://www.unhabitat.org 